\title{
US GAAP Conversion To IFRS: A Case Study Of The Cash Flow Statement
}

Peter Harris, New York Institute of Technology, USA

William Stahlin, Stevens Institute of Technology, USA

Moade Fawzi Shubita, New York Institute of Technology, USA

\begin{abstract}
International Reporting Standards (IFRS) has become the required framework for most of the world financial market economies as of January 1, 2011. This includes, in a non-comprehensive listing, the many European Union countries - Canada, Australia and New Zealand. In the United States, US Generally Accepted Accounting Principles (GAAP) is still required. However, plans are presently in place by the SEC to abandon US GAAP and to adhere to IFRS requirements by as early as for the period ending December 31, 2014. As such, it is important to introduce IFRS accounting rules in the college curriculum and make it a major component of accounting classes. This case study takes a US GAAP Prepared Cash Flow Statement and, based on the facts of the case, requires students to prepare an IFRS-based Cash Flow Statement. The need to understand both US GAAP and IFRS rules is required to adequately address this case study, which is most suitable for an Intermediary Accounting, Accounting Theory and a Financial Statement Analysis class, as well as an Investment Finance course, at the graduate level.
\end{abstract}

Keywords: US GAAP; IFRS; Statement of Cash Flows; LIFO; Capital/Financing Lease; Operating Lease

\section{INTRODUCTION}

\section{Background}

XE Corp, a publically traded NASDAQ company (symbol AXEC), is a manufacturer of electrical light bulbs. Its main headquarters is based in Denver, Colorado, and the company has been operating since 1976. The company sells light bulbs to the retail market on a worldwide basis. Its major clientele is Home Depot and Lowes and has captured about 10 percent of the world market of light bulbs sales.

Their Cash Flow Statement presented below for the Year Ending December 31, 2011 has been prepared using US GAAP. The company has opted to use the Direct Method as it believes it adds transparency and is more fundamentally sound than the indirect method. The controller would like to begin to see the effects of using IFRS on the Cash Flow Statement and has been assigned this task. In particular, the controller would like to see the different effects on Cash Flow presentation between US GAAP and IFRS. The company would like to adapt IFRS by as early as next year as it is considering a new stock issue in the London Stock Exchange, which requires IFRS compliance. 


\title{
AXE CORP. \\ Cash Flow Statement (Direct Method) under US GAAP 1/1/2011-12/31/2011
}

\author{
Cash Flow from Operations \\ Collections from Sales $\$ 246,000$ \\ Cash paid to Suppliers $\quad(183,000)$ \\ Cash paid for Operating Expenses $\quad(29,000)$ \\ Cash paid for Interest Expense $\quad\left(\begin{array}{r}4,000) \\ \text { Cash }\end{array}\right.$ \\ Cash paid for Income Taxes $\quad(9,000)$ \\ Cash Flow Provided from Operating Activities $\quad 21,000$ \\ Cash Flow from Investing \\ Purchase of Equipment \\ $(13,000)$ \\ Cash Flow from Financing Activities \\ Cash Dividends paid \\ Net Increase in Cash for the Year $2011 \quad \frac{(3,000)}{5,000}$ \\ Beginning Cash Balance $\quad 28,000$ \\ Ending Cash balance 12/31/2011 $\$ \underline{\$ 33,000}$
}

\section{Additional Information}

Axe entered into a lease on January 1, 2011 with the following terms:

- $\quad$ Axe leased specialized machinery manufactured by the lessor, Bell Corp., which will enable Axe to manufacture their light bulbs in a much more efficient manner. This machinery does not have a resale market and was made specifically for AXE to meet its specifications.

- $\quad$ The lease term is for three years with a lease payment made to the lessor in the amount of $\$ 5,000$. Payment is due on December 31 of each year with the first payment due on December 31, 2011. At the end of the lease term, ownership reverts back to the lessor. There is no option to buy the equipment.

- $\quad$ The lessee will pay all executor costs.

- $\quad$ The estimated useful life of the lease is 49 months - 4 and $1 / 12$ years.

- $\quad$ The fair market value of the equipment is $\$ 15,000$.

- $\quad$ The implicit rate of Bell Corp. is 6 percent and is known to the lessee, Axe.

- $\quad$ The incremental borrowing rate of Axe is 7 percent.

- $\quad$ This lease is treated as an operating lease under US GAAP and the US GAAP-prepared Cash Flow Statement reflects this.

- $\quad$ Under IFRS, this lease is treated as a capital/financing lease.

- AXE uses the LIFO inventory method of accounting. The LIFO reserve is $\$ 7,000$ at the beginning of the year and $\$ 11,000$ at the end of the year.

- $\quad$ The tax rate for AXE is 30 percent. All current tax obligations are paid when accrued.

- $\quad$ Assume that AXE has elected to treat interest expense as a cash flow from operations activity, thereby being consistent with the US GAAP-prepared statement.

\section{Required}

For the scenario above:

1. Differentiate between an Operating Lease and a Capital/Financing Lease for financial reporting purposes.

2. What are the effects, if any, on the IFRS Cash Flow Statement?

3. What is the effect on the Cash Flow Statement by the use of LIFO for US GAAP and FIFO for IFRS? 
4. Prepare a Cash Flow Statement under IFRS for Year 1 and identify any other differences in cash flow presentation between IFRS and US GAAP. Axe has elected to treat all interest expense payments as cash flows from continuing operations.

NOTE: The focus here is only on the Cash Flow Statement.

\section{SUGGESTED SOLUTIONS}

\section{Part 1}

An operating lease is treated as a rent expense and is recorded on the Income Statement as such. An operating lease is an off Balance Sheet transaction and, as such, is preferred by companies. A Capital Lease - per US GAAP, termed as a Financing Lease under IFRS - is treated as a purchase of Property, Plant and Equipment and is capitalized as such on the Balance Sheet. The minimum lease payments required on the lease are recorded as a liability on the Balance Sheet at the present value amount using the lessee's incremental borrowing or the implicit rate of the lease, if it is lower and known by the lessee. The liability is separated into its current and long-term components. Additionally, the cash payments under an operating lease are treated as a cash outflow from operating activities and, under a capital/financing lease, will be treated as a payment for financing activities (minimum lease obligation amount) and a payment for interest. The interest payment is classified as a cash outflow from operating activities under US GAAP and either as a cash outflow from operating activities or financing activities under IFRS.

\section{Part 2: Effects on IFRS Cash Flow Statement}

Assuming a capital/financing lease, the amortization table is presented below:

\begin{tabular}{lcccc} 
Year & Payment & Interest $\mathbf{- 6 \%}$ & Principal & Minimum Lease Obligation - Payable \$13,365 \\
\hline 1 & $\$ 5,000$ & 802 & 4,198 & 9,167 \\
2 & 5,000 & 550 & 4,450 & 4,717 \\
3 & 5,000 & 283 & 4,717 & 0 \\
\hline Totals & $\$ 15,000$ & 1,635 & 13,365 & N/A
\end{tabular}

Effects on the Cash Flow Statement

$\underline{\text { Year of Lease Inception }}$

In the year of inception, US GAAP treats the $\$ 5,000$ rent expense as an operating lease payment - a cash outflow from continuing Operations as an Operating expense on the income statement.

Under IFRS, the financing/capital lease is treated as a purchase of Property, Plant and Equipment and is capitalized on the Balance Sheet as such - in the amount of $\$ 13,365$ - with a corresponding liability in this amount. The payment of $\$ 5,000$ effects the Cash Flow Statement which results in a cash payment of the minimum lease obligation - a cash outflow from Financing Activities in the amount of $\$ 4,198$ and an interest payment - a cash outflow from Financing Activities or Operating Activities for $\$ 802$, keeping the same total payment amount of $\$ 5,000$.

Subsequent to Year of Inception-Years 2 and 3 of Lease Payments

\section{$\underline{\text { US GAAP }}$}

The \$5,000 annual Lease payment is treated as a rent expense - a cash outflow from Continuing Operations as an Operating expense. 
$\underline{\text { IFRS }}$

The $\$ 5,000$ lease payment is treated as an interest expense payment and a reduction in the liability Minimum lease obligation Under Financing/Capital Lease in the amounts enumerated above per years 1, 2 and 3 calculations. The interest expense is treated either as a cash Outflow from Continuing Operations or a financing activity payment, and the minimum lease obligation payment is treated as a cash outflow from financing activities.

\section{Part 3}

IFRS disallows the use of LIFO as an acceptable accounting method. LIFO is allowed under US GAAP and, if used for financial reporting purposes, has to be used for tax purposes - known as the conformity rule. In this case, IFRS will require the use of FIFO and the differential between the cost of goods sold and pre-tax total between LIFO and FIFO will equal the difference in the beginning and the end of year LIFO Reserve. This amount is $\$ 11,000$ less $\$ 7,000$, which equals an increase in pre-tax income under FIFO, by virtue of a higher ending inventory total and lower cost of goods sold amount of $\$ 4,000$. At a tax rate of 30 percent, this amounts to a greater cash tax payment of $\$ 1,200$ under FIFO.

This will cause a decrease in cash flow under IFRS by virtue of FIFO use. Cash will be reduced by $\$ 1,200$ to $\$ 31,800$.

\section{Part 4}

\section{AXE CORP. \\ Cash Flow Statement (Direct Method) US GAAP to IFRS Reconciliation 1/1/2011-12/31/2011}

\section{Cash Flow from Operations}

Cash Collections from Sales

Cash paid to Suppliers

Cash paid for Operating Expenses

Cash paid for Interest Expense

Cash paid for Income Taxes

Cash Flow Provided from Operating Activities

Cash Flow from Investing

Purchase of Equipment

Cash Flow from Investing Activities

\section{US GAAP}

$\$ 246,000$

( 29,000$)$

( 4,000$)$

$(9,000)$

21,000
$(183,000)$

ADJUSTMENTS

\begin{tabular}{lc} 
& \\
(1) & 5,000 \\
(1) & $(\quad 802)$ \\
$(2)$ & $(1,200)$ \\
\hline & 2,998
\end{tabular}

$(13,000)$

$\underline{(13,000)}$
IFRS Cash Flow

246,000

$(183,000)$

$(24,000)$

( 4,802$)$

$(10,200)$

23,998

\section{Cash Flow from Financing Activities}

Cash Dividends paid

Payment of Minimum Lease Obligation

Liability

Cash Flow From Financing Activities

Net Increase in Cash for the Year 2011

Beginning Cash Balance

Ending Cash balance 12/31/2011

$(3,000)$

$\begin{array}{r} \\ (1) \quad(4,198) \\ (4,198) \\ (1,200) \\ (1,200) \\ \hline\end{array}$

$(13,000)$

$(13,000)$

\section{Notes:}

(1) The $\$ 5,000$ has been reclassified as a result of operating to capital/financing lease treatment under IFRS.

(2) The decrease of $\$ 1,200$ cash is a result of higher taxes paid by virtue of additional income of $\$ 4,000$, by the use of FIFO-as LIFO is not acceptable under IFRS (30 percent tax rate times 4,000 results in $\$ 1,200$ of additional tax). 


\title{
AXE CORP. \\ Cash Flow Statement (Direct Method): IFRS Prepared 1/1/2011-12/31/2011
}

\author{
Cash Flow From Operations \\ Cash Collections from Sales \\ Cash paid to Suppliers \\ Cash paid for Operating Expenses \\ Cash paid for Interest Expense \\ Cash paid for Income Taxes \\ Cash Flow Provided from Operating Activities \\ Cash Flow From Investing \\ Purchase of Equipment \\ Cash Flow from Investing Activities \\ Cash Flow From Financing Activities \\ Cash Dividends paid \\ Payment of Minimum Lease Obligation Liability \\ Cash Flow From Financing Activities \\ Net Increase in Cash for the Year 2011 \\ Beginning Cash Balance \\ Ending Cash balance 12/31/2011
}

$\$ 246,000$

$(183,000)$

( 24,000$)$

( 4,802)

$(10,200)$

$\frac{(13,000)}{(13,000)}$

23,998
( 3,000$)$
$(4,198)$
$(7,198)$
3,800
$\underline{28,000}$
$\$ 31,800$

Other Differences between US GAAP and IFRS Cash Flow Statement Classifications

Interest Expense is treated either as a cash flow from operations or a cash flow from financing for IFRS purposes. For US GAAP, interest expense is a cash outflow from continuing operations. Additionally, Interest Revenue and Dividend Revenue, under IFRS, is treated either as a cash flow from operations or a cash flow from investing activity, whereas under US GAAP, these items are treated as cash inflows from operating activities.

\section{CONCLUSION}

IFRS is the future of worldwide financial reporting and should be included as a major part of any accounting and/or business curriculum in the US, as well as the rest of the world. This case illustrates a situation where a Cash Flow Statement is prepared using US GAAP as a basis and converting to IFRS for comparison purposes. In this case study, IFRS rules are discussed and key Cash Flow similarities and differences between US GAAP and IFRS are addressed.

\section{AUTHOR INFORMATION}

Peter Harris is a Professor and Chair of the Accounting and Finance department at the New York Institute of Technology. Previously, he has worked for Ernst and Young LLP. He is an author of over 50 refereed journal articles and over 130 intellectual contributions. E-mail: pharris@ @yit.edu (Corresponding author)

Bill Stahlin is an Affiliate Associate Professor at Stevens Institute of Technology. He is the mid - Atlantic regional coordinator for the American Accounting Association's teaching, learning and curriculum section. He's made numerous presentations on teaching pedagogy and co-authored an instructor training course while at Coopers \& Lybrand. E-mail: wstahlin@stevens.edu

Moade Fawzi Shubita is a professor at the New York Institute of Technology. He has been teaching for 15 years and was the Associate Dean of the NYIT Middle East campus. He has many publications relating to earnings management and IFRS topics. E-mail: moade_shubita@hotmail.com 


\section{REFERENCES}

1. International Financial Accounting Standards (IFRS). IAS numbers: 2, 3, 5, 17, 36, 37, 38, 39.

2. U.S Generally Accepted Accounting Principles (US GAAP). FASB 13, 95, ASC Numbers: 320, 330, 360, 410,985 . 